University for Business and Technology in Kosovo

UBT Knowledge Center

Nov 7th, 3:00 PM - 3:15 PM

\title{
The design of durable concretes, produced by traditional mountain aggregate, in different environments
}

\author{
Alma Golgota \\ Polytechnic University of Tirana, almagolgota@uamd.edu.al \\ Rezarta Qemallaj \\ Aleksander Moisiu University \\ Boriana Vrusho
}

Follow this and additional works at: https://knowledgecenter.ubt-uni.net/conference

Part of the Architecture Commons

\section{Recommended Citation \\ Golgota, Alma; Qemallaj, Rezarta; and Vrusho, Boriana, "The design of durable concretes, produced by traditional mountain aggregate, in different environments" (2014). UBT International Conference. 22. https://knowledgecenter.ubt-uni.net/conference/2014/all-events/22}

This Event is brought to you for free and open access by the Publication and Journals at UBT Knowledge Center. It has been accepted for inclusion in UBT International Conference by an authorized administrator of UBT Knowledge Center. For more information, please contact knowledge.center@ubt-uni.net. 


\title{
The design of durable concretes, produced by traditional mountain aggregate, in different environments
}

\author{
Alma Golgota ${ }^{1}$, Rezarta Qemallaj ${ }^{2}$, Boriana Vrusho ${ }^{3}$ \\ ${ }^{1}$ Polytechnic University of Tirana, Albania \\ ${ }^{2}$ Engineering Science Dept. - University of “A. Moisiu”, Durres, Albania \\ 1. almagolgota@uamd.edu.al; almagolgota@yahoo.com
}

\begin{abstract}
This article describes the effect of durable concrete in two different environments, which is produced by traditional mountain aggregates. For this purpose, we have produced concrete of class C30/37 with aggregates from mountain quarry. Meanwhile, we have not changed other components of concrete. Water - cement report is 0.4-0.61. During experimental faze, are done comparisons of resistance to compression, water and chlorides penetration for specimens of concrete which are curing in normal environment $(\mathrm{N})$ and in marine environment $(\mathrm{A})$. Concrete cubes produced, were treated in marine and normal environment for 3, 7 and 28 days in Durres coastal city, Albania. Finally, results are compared to each other and conclusions are made on this basis.
\end{abstract}

Keywords: chloride permeability, traditional aggregate, strength durable concrete, depth of penetration

\section{Introduction}

Although concrete structures are thought as long-lived, their longevity is frequently affected by many factors as aggressive environments and inappropriate concrete ingredients. Through years, grew up the concern about durability of concrete structures. Many studies and experiments were made in this direction, to produce concrete, which would resist more external and internal reactions. Parallel to this, construction methods should change and use practices that are more appropriate.

Concrete durability depends on: exposure conditions (soil; sea water; de-icing salt; stored chemical or atmosphere), cement type, concrete quality (cover of the reinforcement, adequate cover), prevention of corrosive agents, safe transfer of bond forces, safe transfer of bond forces against a rapid rise in temperature during a fire, adequate durability, fire resistance. According to Zhang: "Durability is a comprehensive property of materials. Materials of different compositions and structures have different kinds of durability" (1).

${ }^{1}$ The book - Building Materials in Civil Engineering - H. Zhang (Woodhead, 2011)_BBS

In order to benefit longevity in use of concrete, we should difference two different concepts: possible longevity of concrete and factual longevity of it, as a material to be used in particular environments. Hence, we should take into account characteristics of concrete aggregates to produce water resistant and resistant to chloride concrete placed in marine environment.

Procedure followed for this paper was to produce durable concretes with aggregates taken from two different quarry: one from Kruja Mountain and the other from "Perroi i Thate" Mat river. These aggregates will produce water resistant and chloride resistant concrete with different characteristics. Our aim is to analyze how traditional aggregate affects quality of durable concretes and how shape and size of aggregates influences these concretes.

For the above experiments and analysis we have taken in consideration ISO 7031-1994 standard specifications for resistance to water penetration, or otherwise we have relied on standard EN 206-1 (permeability should be up to 20 to $50 \mathrm{~mm}$ ). 


\section{Materials and Methodology}

Methodology used for this article is making experiments to produce concretes by traditional aggregates according to Albanian Standard S SH EN 206-1:2003, with resistance class C30/37. These aggregates were taken in Kruja mountain, from Fushe Kruje, aggregates production site and from "Perroi i Thate" from Mat River, Koplik, Albania. Based on findings derived from experiments, are drown some analysis and conclusions.

\subsection{Materials}

\subsubsection{Cement}

Details of the experimental program have been reported in this study. Concrete ingredients produced according to the Albanian standard S SH EN 206-1:2003, with resistance class C30/37.

Composition of Portland cement, CEM I 42.5 R, from ANTEA, type cement conforming EN 197-1 was used in this study. In tab. 1-3 are shown the chemical composition and properties of cement:

Table 3. Chemical Composition of CEM I 42.5 R TITAN cement

\begin{tabular}{llccc}
\hline No. & $\begin{array}{c}\text { Chemical } \\
\text { composition }\end{array}$ & Units & Test results & $\begin{array}{c}\text { Standard limit based on } \\
\text { EN 197-1 standard }\end{array}$ \\
$\mathbf{1}$ & $\mathrm{SiO}_{2}$ (Min.) & $\%$ & 18.01 & - \\
$\mathbf{2}$ & $\mathrm{Fe}_{2} \mathrm{O}_{3}$ (Min.) & $\%$ & 2.69 & - \\
$\mathbf{3}$ & $\mathrm{Al}_{2} \mathrm{O}_{3}$ (Min.) & $\%$ & 4.58 & - \\
$\mathbf{4}$ & $\mathrm{MgO}_{\text {(Max.) }}$ & $\%$ & 1.80 & $\mathbf{5 . 0 0 \%}$ \\
$\mathbf{5}$ & $\mathrm{CaO}_{\text {Min.) }}$ & $\%$ & 61.23 & $\mathbf{1 0 . 0 0 \%}$ \\
$\mathbf{6}$ & $\mathrm{SO}_{3}$ (Max.) & $\%$ & 2.67 & $\mathbf{3 . 5 0 \%}$ \\
$\mathbf{7}$ & (Cl) (Max.) & $\%$ & - & $\mathbf{0 . 1 0 \%}$ \\
$\mathbf{8}$ & I. $\mathrm{R}$ (Max.) & $\%$ & 0.3 & $\mathbf{5 . 0 0 \%}$ \\
\hline
\end{tabular}

Table 2. Physical Properties of CEM I 42.5 R TITAN Cement

\begin{tabular}{clccc} 
No. & $\begin{array}{l}\text { Physical } \\
\text { characteristics }\end{array}$ & Units & Test results & EN 197-1 Standard limit \\
$\mathbf{1}$ & $\begin{array}{l}\text { Specific } \\
\text { surface, Blaine }\end{array}$ & $\mathrm{cm}^{2} / \mathrm{g}$ & 3842 & \pm 200 \\
$\mathbf{2}$ & $\begin{array}{l}\text { Specific } \\
\text { density }\end{array}$ & $\mathrm{g} / \mathrm{cm}^{3}$ & - & \pm 50 \\
$\mathbf{3}$ & $\begin{array}{l}\text { Standard } \\
\text { consistency }\end{array}$ & $\%$ & 28 & - \\
$\mathbf{4}$ & $\begin{array}{l}\text { Initial setting } \\
\text { time }\end{array}$ & $\min$ & $2 \mathrm{~h}: 30 \mathrm{~min}$ & 60 \\
$\mathbf{5}$ & $\begin{array}{l}\text { Final setting } \\
\text { time }\end{array}$ & $\min$ & - & - \\
\hline
\end{tabular}




\begin{tabular}{lllll}
\hline 6 & $\begin{array}{l}\text { Loss on } \\
\text { ignition } \\
(\text { L.O.I) }\end{array}$ & $\%$ & - & $\leq 5 \%$ \\
7 & Expansion & $\mathrm{mm}$ & 0 & $\leq 10 \mathrm{~mm}$
\end{tabular}

Table 3. Mechanical Properties of CEM I 42.5 R TITAN Cement

\begin{tabular}{|c|c|c|c|c|c|}
\hline \multirow[t]{2}{*}{ No. } & \multirow{2}{*}{$\begin{array}{c}\text { Mechanical } \\
\text { characteristics }\end{array}$} & \multirow[t]{2}{*}{ Units } & \multicolumn{3}{|c|}{ Test results } \\
\hline & & & 2 Days & $\begin{array}{c}28 \\
\text { Days }\end{array}$ & $\begin{array}{c}\text { EN 197- } \\
\text { 1Standard } \\
\text { limits }\end{array}$ \\
\hline 1 & $\begin{array}{l}\text { Compressive } \\
\text { strength }\end{array}$ & $\mathrm{N} / \mathrm{mm}^{2}$ & 26.69 & 46.75 & $\begin{array}{l}2 \text { Days }>20 \\
\mathrm{MPa} \\
28 \mathrm{Days} \geq \\
42.5 \text { and } \leq \\
62.5 \mathrm{MPa}\end{array}$ \\
\hline 2 & Flexural strength & $\mathrm{N} / \mathrm{mm}^{2}$ & 4.80 & 7.38 & \\
\hline
\end{tabular}

\subsubsection{Aggregates}

Coarse and fine aggregates units for this study were obtained from "Perroi i Thate", Mati river, in Koplik and Kruja Mountain quarry, in Fushe Kruja. Maximum size of coarse aggregate used is $25 \mathrm{~mm}$ and specific gravity range is from $2.6-2.7 \mathrm{~kg} / \mathrm{m} 3$ based on standard S SH 509:1987; bulk density 1484 $\mathrm{kg} / \mathrm{m} 3$ and fine modulus 6.07. For fine aggregates maximum size used is $5 \mathrm{~mm}$ and specific gravity range is from $2.687 \mathrm{~kg} / \mathrm{m} 3$, based on standard S SH 509:1987; and fine modulus 2.74. Granulometric analysis are presented below, in fig. 1 for mountain aggregates; and in fig. 2 for river aggregates.

SAMPLE: Natural River Sand 0/8 mm; Rugged River Sand 0/3mm

\&Rugged River granulated stone 6/12.5 mm\&10/25mm

Quarry: "Perroi i Thate", Mati river,

Concrete type: C 30/37 Mpa 

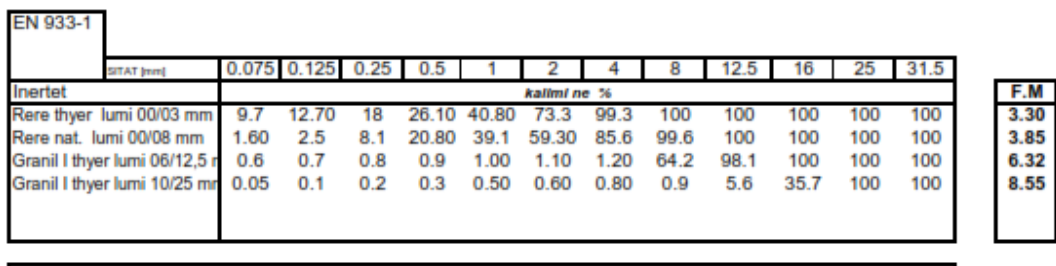

\section{PARACIIJA GRAFFIKE, E ANALIIZES'GRANULOMETRIKETEINERTEVE}

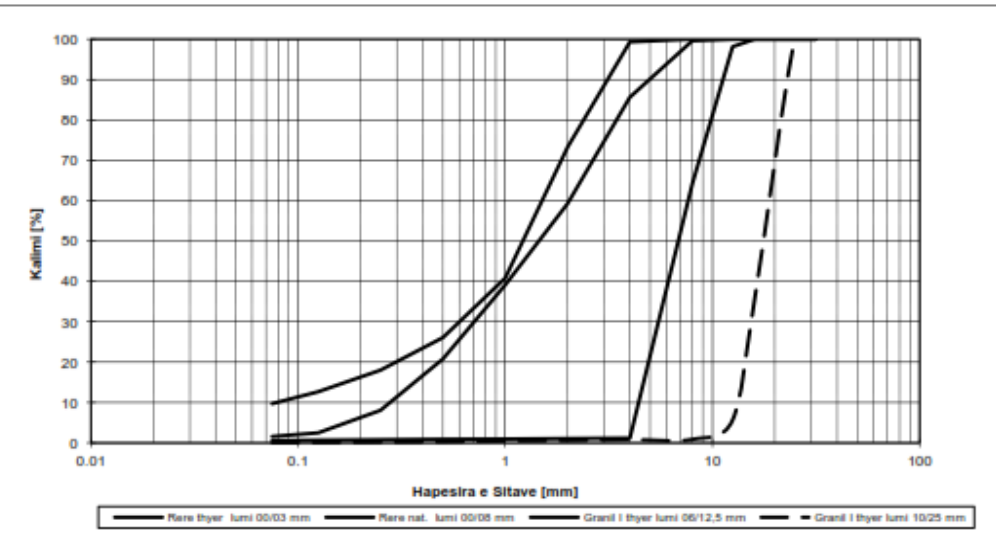

Fig. 4. Sieve analysis of river aggregate

SAMPLE: Mountain Aggregate

Site: $\quad$ Fushe Kruje

Concrete type: C $30 / 37 \mathrm{Mpa}$

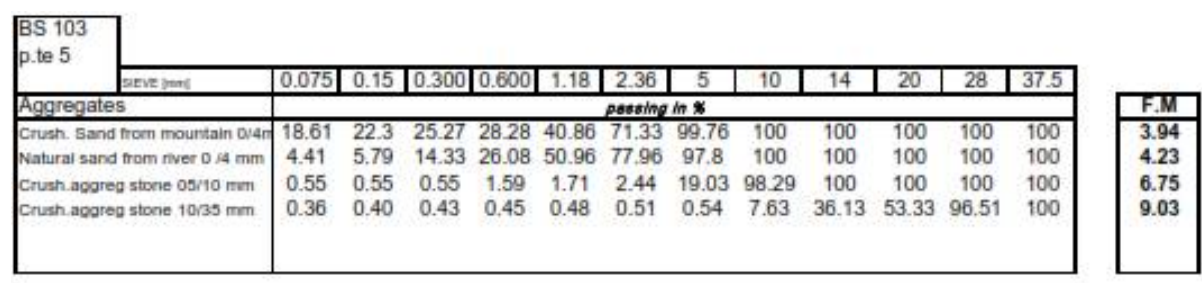

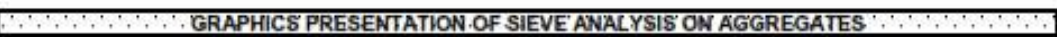

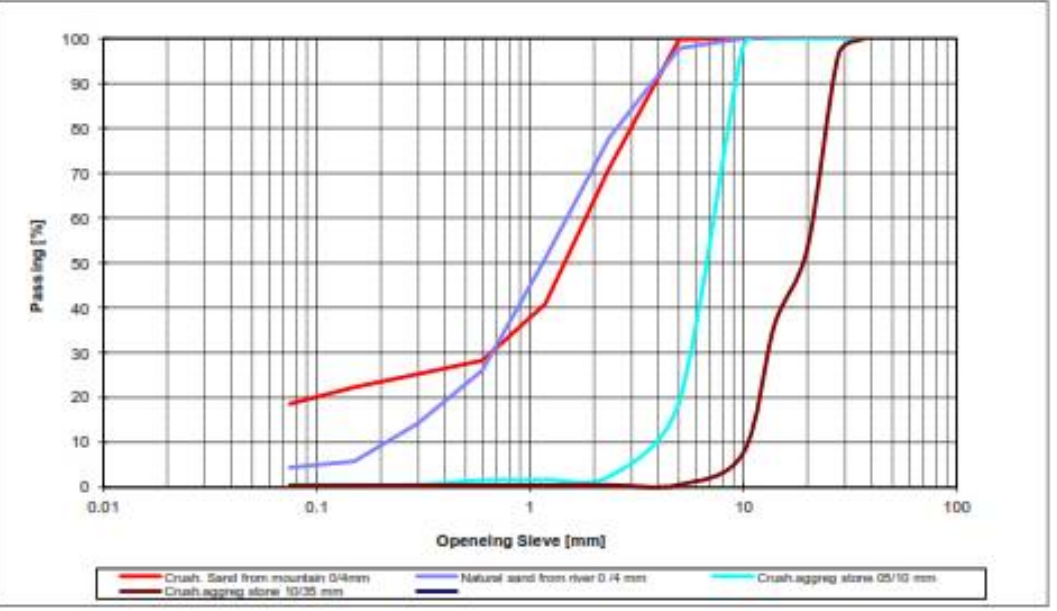

Fig. 2. Sieve analysis of mountain aggregate 


\section{Chemical Compositions}

Table 4. The aggregate chemical composition

\begin{tabular}{|c|c|c|c|c|}
\hline \multirow{2}{*}{$\begin{array}{l}\text { Chemical } \\
\text { composition of } \\
\text { aggregates }\end{array}$} & \multicolumn{4}{|c|}{ Chemical composition in [\%] } \\
\hline & $\mathrm{CaO}$ & MgO & $\mathrm{SiO}_{2}$ & $\mathrm{Fe}_{2} \mathrm{O}_{3}$ \\
\hline $\begin{array}{l}\text { Kruja Mountain } \\
\text { (Fushe Kruje) }\end{array}$ & $\begin{array}{c}43.59- \\
65.83\end{array}$ & 4.23 & 0.18 & 0.12 \\
\hline $\begin{array}{l}\text { "Perroi i Thate" } \\
\text { (Mat River) }\end{array}$ & 4.68-9.37 & $\begin{array}{l}13.3- \\
29.05 \\
\end{array}$ & $43.67-50.2$ & $5.67-6.67$ \\
\hline
\end{tabular}

Table 5. The aggregate Physic Characteristics

\begin{tabular}{|c|c|c|c|c|}
\hline Physic & & & & \\
\hline $\begin{array}{l}\text { Characteristics of } \\
\text { aggregates } \\
\text { ASTM } 1992\end{array}$ & $\begin{array}{l}\text { Density } \\
\mathrm{g} / \mathrm{cm}^{3}\end{array}$ & $\begin{array}{c}\text { Resistance } \\
\text { to } \\
\text { compression } \\
\text { MPa }\end{array}$ & $\begin{array}{c}\text { Elasticity } \\
\text { Module } \\
\text { E=б/€ } \\
\text { MPa }\end{array}$ & $\begin{array}{c}\text { Absorption } \\
\text { Coefficient } \\
\%\end{array}$ \\
\hline $\begin{array}{l}\text { Kruja Mountain } \\
\text { (Fushe Kruje) }\end{array}$ & $1.3-1.7$ & 11.3 & $>70$ & $0.5-0.9$ \\
\hline $\begin{array}{l}\text { "Perroi i Thate" } \\
\text { (Mat River) }\end{array}$ & $2.6-2.7$ & 15.98 & 48.36 & $0.5-1.6$ \\
\hline
\end{tabular}

The above values are taken from “American Society for Testing and Materials" study, Albania

\subsubsection{Water}

Potable tap water available from the production site was used for mixing and curing of concrete. The water is filtrate based on standard S SH 2751:1987. Chemical analysis of water used in mix design are shown in tab.6:

Table 6. Chemical analysis of water used in mix design

\begin{tabular}{llccc}
\hline No. & \multicolumn{1}{c}{ Characteristics } & Units & Test results & $\begin{array}{c}\text { Standard limit } \\
\text { EN 1008 }\end{array}$ \\
& & & & \\
$\mathbf{1}$ & Water resource & & Well water & - \\
$\mathbf{2}$ & Colour & & Transparent & - \\
$\mathbf{3}$ & Odour & & None & - \\
$\mathbf{4}$ & Water density @ 190 C & $\mathrm{kg} / \mathrm{l}$ & 1.0082 & 0.9982 \\
$\mathbf{5}$ & Total hardness (CaCO3) & $\mathrm{mg} / \mathrm{l}$ & 2.91 & - \\
$\mathbf{6}$ & Total dissolved solids at $180{ }^{\circ} \mathrm{C}$ & $\mathrm{mg} / 1$ & 3.82 & $\leq 4$ \\
$\mathbf{7}$ & pH value & & 7.61 & $\geq 4$ \\
$\mathbf{8}$ & Chloride content Cl- & $\mathrm{mg} / \mathrm{l}$ & 1241 & $\leq 1000$ \\
\hline
\end{tabular}




\begin{tabular}{clccc}
\hline $\mathbf{9}$ & Sulphate content SO4- & $\mathrm{mg} / \mathrm{l}$ & 4996 & $\leq 2000$ \\
$\mathbf{1 0}$ & Salts content & $\mathrm{mg} / \mathrm{l}$ & 0.02 & $\leq 100$ \\
\hline
\end{tabular}

\subsubsection{Concrete admixtures}

Additives used in this experiment are: Chryso-Fluid Premia 180(super plasticizer) and in quantities 3 $1 / \mathrm{m} 3$ concrete. Additives were used to produce concrete class C 30/37 MPa and the result was decreasing the amount of water. The effect of using the lowest amount of water is increasing the durability and resistance of concrete.

\subsection{Methodology}

\subsubsection{Durable concrete mix design}

Mix design is the process of selecting suitable ingredients for producing concrete and determining the proportions to produce, as economically as possible, concrete that satisfies Orion project requirements.

All mix designs data for durable concrete used in our project are represented in Table 2. In this study durable concrete class C30/37 was produced with river raw material. All mix designs are formulated based on specifications of EN 206-1:2003 standard. Aggregates taken from mountain originate from carbonate rocks, with high content of limestone. Meanwhile, river aggregates have volcanic origin and therefore have high content of basalt.

Eurocode EN206-1 requests for durable concretes are:

- In order to guarantee a structure with an appropriate lifetime, should consider the following factors connected between them:

- Service required criteria

- Expected environmental conditions

- Composition of the form structure of the building

- Qualities and suitability of materials;

- Quality of implementation and level of control;

- The use of the structure

- Environmental conditions should be evaluated in the phase of the project to assess their meaning in relation to longevity and to predict appropriate measures for the protection of materials. In tab.7 is given the mix design of concrete on class 30/37 composed with aggregate from Kruja mountain:

\section{Date of production 30.09.2013}

Table 7. Mix design of concrete from Kruja Mountain

\begin{tabular}{clcc}
\hline No. & \multicolumn{1}{c}{ Ingredients } & Units/m & Quantity \\
\hline $\mathbf{1}$ & Crashed sand 0-04 mm & $\mathrm{kg}$ & 895 \\
$\mathbf{2}$ & Crashed river gravel 5-10 mm & $\mathrm{kg}$ & 298 \\
$\mathbf{3}$ & Crashed river gravel 10-25mm & $\mathrm{kg}$ & 698 \\
$\mathbf{4}$ & Cement CEM I 45.2 R/A-LL & $\mathrm{kg}$ & 340 \\
\hline
\end{tabular}




\begin{tabular}{clcc}
\hline $\mathbf{5}$ & $\begin{array}{l}\text { Additive } \\
\text { Chryso-Fluid Premia 180 (superplasticizer) } \\
\end{array}$ & lit $/ \mathrm{m}^{3}$ & 3.32 \\
& $\begin{array}{l}\text { Reduction. 15\%; } \\
\text { Dosage 0.8 lit/100 kg cement) }\end{array}$ & & \\
$\mathbf{6}$ & Well water & lit & 151 \\
$\mathbf{7}$ & w/c ratio & - & $\mathbf{0 . 4 4}$ \\
$\mathbf{8}$ & Density UNI 6394 & $\mathrm{kg}$ & $\mathbf{2 3 8 5}$ \\
$\mathbf{9}$ & Fresh concrete temperature & ${ }^{\circ} \mathrm{C}$ & 19 \\
$\mathbf{1 0}$ & Slump UNI 9418 & $\mathrm{mm}$ & $10-15$ \\
\hline
\end{tabular}

In tab.8 is given the mix design of concrete on class 30/37 composed with aggregate from Mati River:

Date of production 01.10.2013

Table 8. Mix design of concrete from Mati River

\begin{tabular}{clcc}
\hline No. & \multicolumn{1}{c}{ Ingredients } & Units $/ \mathbf{m}^{\mathbf{3}}$ & Quantity \\
\hline $\mathbf{1}$ & Natural river sand 0-04 mm & $\mathrm{kg}$ & 894 \\
$\mathbf{2}$ & Natural river gravel 5-10 mm & $\mathrm{kg}$ & 311 \\
$\mathbf{3}$ & Natural river gravel 10-25mm & $\mathrm{kg}$ & 738 \\
$\mathbf{4}$ & Cement CEM I 45.2 R/A-LL & $\mathrm{kg}$ & 340 \\
$\mathbf{5}$ & Additive & $\mathrm{lit} / \mathrm{m}^{3}$ & 3.56 \\
& Chryso-Fluid Premia 180 (superplasticizer) & & \\
& Reduction. 15\%; & & \\
$\mathbf{6}$ & Dosage 0.8 lit/100 kg cement) & lit & 142.8 \\
$\mathbf{7}$ & Well water & - & $\mathbf{0 . 4 2}$ \\
$\mathbf{8}$ & Density UNI 6394 & $\mathrm{Kg} / \mathrm{m}^{3}$ & $\mathbf{2 4 2 9}$ \\
$\mathbf{9}$ & Fresh concrete temperature & ${ }^{\circ} \mathrm{C}$ & 19 \\
$\mathbf{1 0}$ & Slump UNI 9418 & $\mathrm{mm}$ & $10-15$ \\
\hline
\end{tabular}

The compressive strength of concrete is considered as the index of its quality. Therefore, mix design concretes are generally carried out for particular compressive strength of concrete with adequate workability so that fresh concrete can be properly mixed, placed and compacted.

After 28 days period of curing, the specimens were taken out of the curing tank and were tested besides measuring the fresh properties (workability, air content and concrete temperature).Following tests such as permeability of concrete cubes and chlorides contents were measured.

\section{Results and Tables}

\subsection{Compressive strength of concrete cubes}

Compressive strength of mixtures was determined at various ages as per EN 12390-3:1999 and EN 12390-5:1999 are shown in table 3.1. Cube Compressive strength at the age 3, 7 and 28 days. After casting, the specimens were covered with sheets to minimize the moisture loss from them. Specimens 
were demoded after 24-hours and then cured in water at approximately room temperature until testing. Compressive strength tests for cubes were carried out at 28 days. All the specimens were tested in an automated compressive strength machine shown in Tab. 9 and the conditions of production and curing are shown in fig.3.

Table 9. Test results obtained from durable concrete produced

\begin{tabular}{|c|c|c|c|c|c|c|}
\hline \multirow[t]{2}{*}{$\begin{array}{l}\text { Curing } \\
\text { Age } \\
\text { (days) }\end{array}$} & \multicolumn{3}{|c|}{$\begin{array}{c}\text { Normal water curing condition } \\
\text { (Kruja Mountain crashed } \\
\text { aggregates) }\end{array}$} & \multicolumn{3}{|c|}{$\begin{array}{l}\text { Normal water curing condition } \\
\text { (Mat River aggregates) }\end{array}$} \\
\hline & $\begin{array}{l}\text { Compres } \\
\text { sive } \\
\text { strength } \\
\text { ( MPa) } \\
\text { EN } \\
12390-3\end{array}$ & $\begin{array}{l}\text { Depth of } \\
\text { water } \\
\text { penetrati } \\
\text { on }(\mathrm{mm}) \\
\text { EN } \\
12390-8\end{array}$ & $\begin{array}{l}\text { Concrete } \\
\text { chloride } \\
\text { content } \\
(\%) \\
\text { EN 196-2 }\end{array}$ & $\begin{array}{l}\text { Compres } \\
\text { sive } \\
\text { strength } \\
\text { ( MPa) } \\
\text { EN } \\
12390-3\end{array}$ & $\begin{array}{l}\text { Depth of } \\
\text { water } \\
\text { penetrat } \\
\text { ion } \\
(\mathrm{mm}) \\
\text { EN } \\
12390-8\end{array}$ & $\begin{array}{l}\text { Concrete } \\
\text { chloride } \\
\text { content } \\
(\%) \\
\text { EN 196-2 }\end{array}$ \\
\hline 3 & 18.23 & & & 23.88 & & \\
\hline 3 & 18.57 & & & 23.93 & & \\
\hline 3 & 13.8 & & & 23.6 & & \\
\hline 7 & 28.33 & & & 32.63 & & \\
\hline 7 & 28.63 & & & 33.25 & & \\
\hline 7 & 26.34 & & & 33.47 & & \\
\hline 28 & 42.33 & 21.75 & 0.036 & 41.33 & 11.64 & 0.021 \\
\hline 28 & 41.23 & 23.31 & 0.042 & 41.36 & 13.71 & 0.023 \\
\hline 28 & 40.63 & 26.04 & 0.045 & 40.89 & 15.23 & 0.034 \\
\hline
\end{tabular}

Fig. 3. Concrete specimens produced in Euro Aditiv Laboratory and curing in the sea shore of Durres city, Albania 


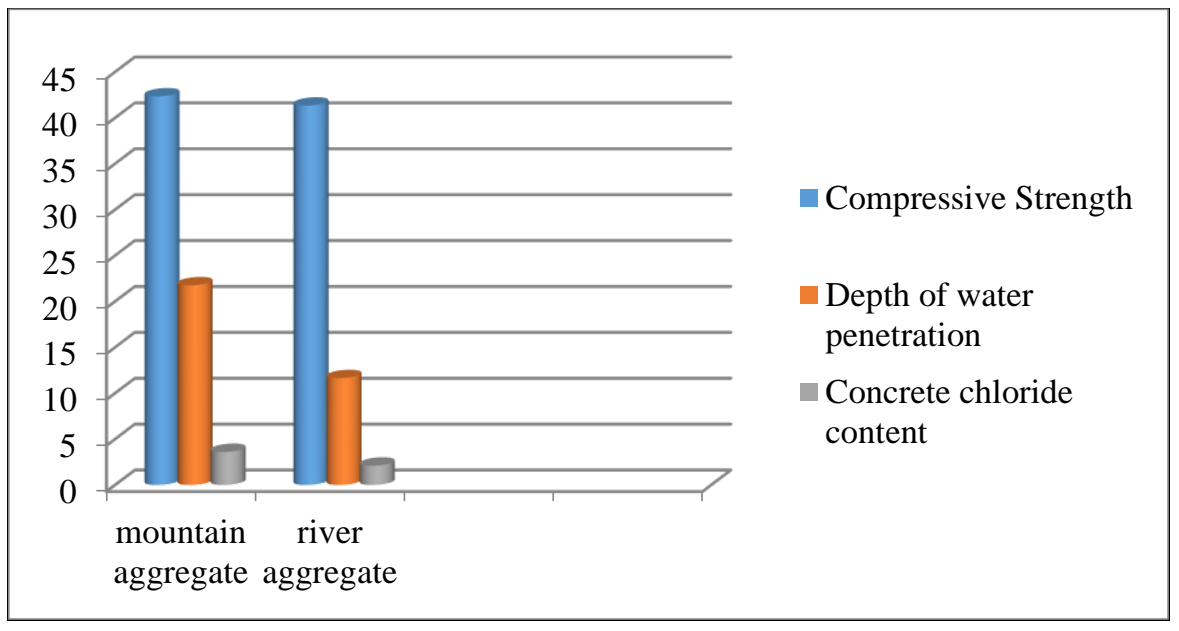

Fig. 4. Relation between Compressive Strength, depth of water penetration, chloride content

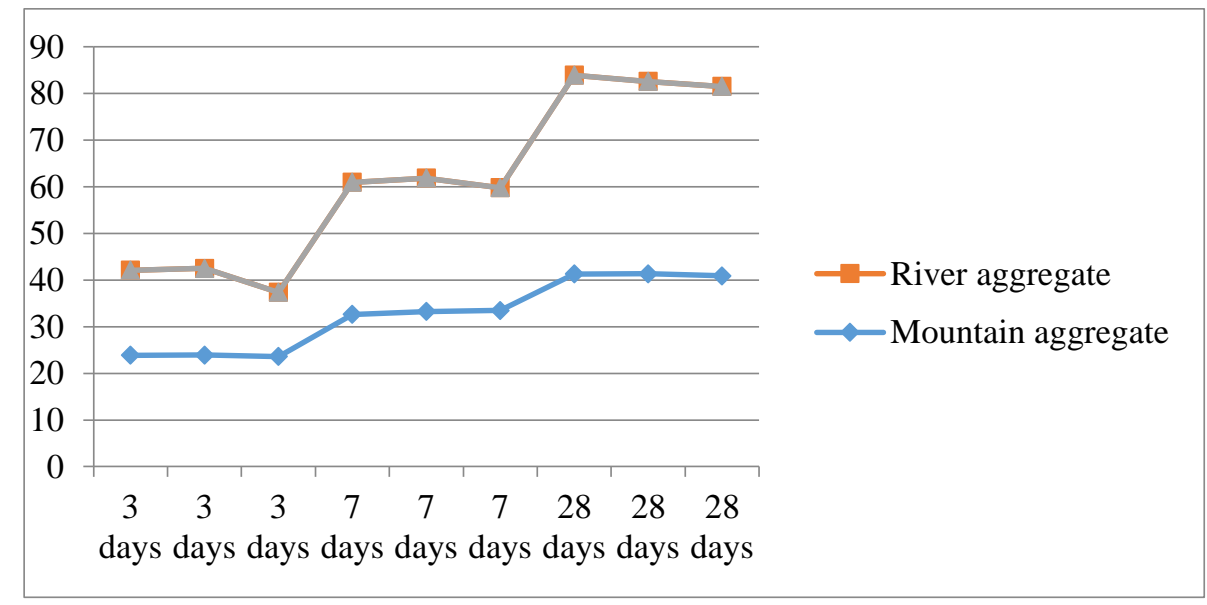

Fig. 5. Relation between Compressive Strength for mountain aggregates and river aggregates

\subsection{Durability of concrete}

The durability of concrete depends largely on the movement of water, which enters and moves through it. Permeability is the measure of water flow under pressure in a saturated porous medium material. Meanwhile, absorption is materials ability to absorb and transmit water through it by capillary suction. The porous structure of concrete is intimately related with its permeability. A low water/cement ratio result in concrete structures, which are less permeable because they have small pores, which are not interconnected. The water penetration under pressure test is a standard test procedure (EN 12390-8).

\section{Conclusions}

It is very important production and usage of durable concretes in structures exposed in marine environment.

Mechanical resistance of durable concrete, for both type of aggregates used, is related to water/cement ratio. Testing results are high for both aggregates.

Mechanical resistance of durable concretes depends on the chemical and Physic Characteristics of the constituent aggregates. 
Rugged mountain aggregates, which have a high percentage of limestone, so have a higher content of $\mathrm{CaCo} 3$, provide concrete with resistance almost identical with river aggregates but have water and chloride penetration over the standard $(20 \mathrm{~mm})$.

River aggregates, especially when they have volcanic origin with high content of basalt, $\mathrm{SiO} 2$ and $\mathrm{MgO}$, have higher density. They produce concretes with high resistance, little permeability to water and chloride.

This kind of aggregates, placed in marine environments, create a protective layer non-permeable to chlorides.

\section{Acknowledgments}

I would like to thank all those people who have been involved directly or indirectly with my research work.

I appreciate the valuable support of my friends and colleagues, during the implementation of this research, including construction company, concrete production site company, the additives supply company, testing laboratories. KIBE1, ALTEA\& GEOSTUDIO 2000 testing laboratories; Euro Aditiv the additives supply company; SAG concrete production site company.

\section{References}

1. “American Society for Testing and Materials" study, Albania

2. Test Result KIBE1 Laboratory

3. Test Result A.L.T.E.A\&GEOSTUDIO 2000 Laboratory

4. EN 206-1:2003 Concrete specification, performance, production and conformity

5. S SH EN 12390: 2002

6. Eurocode 2: Cement structures design. Generally rules and houses rules.

7. Edited by C.W.Yu and John W. Bull: Durability of Materials and Structures in Building and Civil Engineering

8. Michael S. Mamlouk and John P. Zaniewski: Materials for Civil and Construction Engineers

9. M. Collepardi: Admixtures used to enhance placing characteristics of concrete, Cement Concrete Compose 20 (1998) 103-112

10. Collepardi, M., Marcialis, A., and Turriziani, R.: Penetration of Chloride Ions in Cement Pastes and in Concretes. Journal of American Ceramic Society, Vol. 55 (1972) 534-535

11. M. Collepardi : Concrete Durability in a Marine Environment

12. Significance of Tests and Properties of Concrete and Concrete-Making Materials (STP169D) (LT205)

13. Arum, C., and Udoh, I., 2005." Effect of dust inclusion in aggregate on the compressive strength of concrete", Journal of Science, Engineering and Technology, Vol.12 No. 2, ChykeCee, Enugu. 6170-6184.

14. Coppola, L., Fratesi, R., Monosi, S., Zaffaroni, P. and Collepardi, M.: Corrosion of reinforced concrete in sea water submerged structures. Proceedings of the Third International Conference on Performances of Concrete in Marine Environment, New Brunswick, Canada (1996) 127160

15. Neville A.: Properties of Concrete. Fourth Edition, Pearson Prentice Hall (2005)144-145

16. Edited by John Newman \& Ban Seng Choo: Advanced Concrete Technology. Part 2, Concrete Properties, 8/3-8/9 